\title{
The Principle of Individuation
}

In Schleiermacher's Spinozism as well as in his Short Presentation of the Spinozistic System, both from around 1793-94, he continues his preoccupation with the question of personal identity. In On Freedom Schleiermacher was unable to provide an account that made sense of the idea that an agent is the initiator of an action. In that essay he realized that in denying transcendental freedom and espousing determinism, the agency of the agent disappears, since the causal grounds for each action ultimately can be traced back to events pre-existing the agent. Each representation and desire that arises in the psyche is itself causally necessitated by a prior mental state of the agent, and the first mental state of an agent would itself be the product of efficient causes that preceded the existence of the agent in time. On this view the "agency" of the agent "dissolves into infinitely many infinitesimally small external forces that leave us with nothing to think of as firmly active in the subject" (KGA I.1, 257; 42-3). In Spinozism and in The Short Presentation, Schleiermacher embraces a position fully consonant with this result. Specifically, he argues that there are no genuine individuals, and hence no real (noumenal) agents. As such, there is no way to make sense of the notion that an agent is the initiator of an action. In Spinozism he argues for three principle claims. First, there are no justifiable criteria for making judgments concerning the identity of things. Second, there are no justifiable criteria for making judgments regarding the identity of persons. And third, there are no individuals. Because there are no individuals, there must be only one substance in which everything inheres. Only it has complete reality. His position is developed in relation to the views of Spinoza, Leibniz, Kant, and Jacobi. He rejects Leibniz's views, defends 
Spinoza against many of Jacobi's charges, and adopts Kant's critical, transcendental idealism as his own. ${ }^{1}$ He argues that Kant's critical principles, if thought through to their logical conclusion, ultimately lead to a qualified Spinozism.

This chapter, as well as the following one, will be devoted principally to a careful examination of the arguments Schleiermacher proffers in Spinozism; the material in the Short Presentation will be addressed as well, but mostly insofar as it sheds light on the former essay. In this chapter, I will focus on Schleiermacher's argument, directed principally against Leibniz and the Leibnizians, that there is no such a thing as a principle of individuation. In defending this claim, Schleiermacher provides two major arguments, one epistemological in nature, and another that is metaphysical. First, I very briefly discuss the historical context of Schleiermacher's two pieces on Spinoza, and then proceed to provide an analysis of Schleiermacher's epistemological and metaphysical arguments against the principle of individuation.

${ }^{1}$ In her book The Living God: Schleiermacher's Theological Appropropriation of Spinoza, Julia Lamm calls Schleiermacher's position a "post-Kantian Spinozism." Lamm identifies four themes she believes Schleiermacher develops here and carries through into his later material: monism, determinism, realism, and nonanthropomorphism. The interpretation I offer in this book differs significantly from Lamm's. While the first chapter of Lamm's book, devoted to the Spinoza essays, provides a good overview of the themes that Schleiermacher treats in the essays, it does not sufficiently emphasize that Schleiermacher's principle concern in Spinozism is to argue that there are no genuine individuals and to counter some of the Leibnizian positions adopted by Jacobi. Schleiermacher, however, continued his preoccupation with the question of the individual in the Monologen, revising the position taken in Spinozism in significant ways. As has been recently argued by George di Giovanni in Freedom and Religion in Kant and His Immediate Successors, the problems of freedom and the individual stood at the heart of philosophical disputes in Germany in the late eighteenth century. Di Giovanni takes account of the "set of problems that drove popular philosophy-notably the problem of how to reconcile individual identity with the mechanism of nature" (54). In this and the following chapters I argue that one of Schleiermacher's main goals is to understand the relation of the individual to both the world and to the absolute, both in theoretical and practical terms. This is a dominant theme continued in the Speeches and the Monologen, and is significantly echoed in The Christian Faith as well. Significantly, it was Jacobi who had sounded the alarm regarding the question of the individual. Although he disagreed with him on fundamental points, Schleiermacher held Jacobi in high regard and had even hoped to dedicate the first edition of The Christian Faith to him. It is no surprise that Schleiermacher, too, dedicated significant energies to understanding the place of the individual in light of the attraction that Spinoza's insight held for him. 


\section{THE BACKGROUND}

Schleiermacher begins Spinozism by copying forty-four of F. H. Jacobi's paragraphs in which Jacobi had attempted to present "Spinoza's system in its true form and according to the intrinsic coherence of its parts." 2 These forty-four paragraphs represent the second, and longest, exposition of Spinozism and its spirit presented by Jacobi in his On Spinoza's Doctrine in Letters to Moses Mendelssohn. ${ }^{3}$ Jacobi had argued, famously, that all systematic philosophy leads to fatalism and atheism, and that the philosophy of Spinoza was the clearest and most consistently developed position that results from taking rational thinking to its logical conclusion. Left to its own devices, human reason would end up affirming pantheism. Spinoza is a "consistent rationalist," 4 and "Spinozism is atheism." Furthermore, "all ways of demonstration end in fatalism." 5 As a defender of orthodox theism and freedom of the will, Jacobi argued that these dangerous and fatalistic views could only be refuted through a "salto mortale," or leap of faith.

On Spinoza's Doctrine in Letters to Moses Mendelssohn had appeared in 1785, the same year as Mendelssohn's Morgenstunden, and contains Jacobi's correspondence with Mendelssohn, in which the question of Gotthold Ephraim Lessing's Spinozism was discussed at length. Lessing had died on February 15, 1781. When Jacobi had heard through Elise Reimarus that Mendelssohn planned to write something on Lessing, he became rather anxious. He did not want Lessing to be used as a witness in favor of the theism of the German Enlightenment, and he feared that Lessing's real views would be suppressed. Confident that Elise would relay the message to Mendelssohn, he wrote to Elise,

2 Gérard Vallée, The Spinoza Conversations between Lessing and Jacobi, 118. Vallée's book contains translations of important parts of Mendelssohn's Morgenstunden and An die Freunde Lessing', as well as of F. H. Jacobi's Über die Lehre des Spinoza's and Wider Mendelssohns Beschuldigungen. The material is translated from Heinrich Scholz's Die Hauptschriften zum Pantheismusstreit zwischen Jacobi und Mendelssohn.

3 The forty four paragraphs are in Jacobi's April 1785 letter to Mendelssohn. Cf. Scholz, Hauptschriften, 141-65. These are, unfortunately, left out of Vallée's translation. A complete English translation of Concerning the Doctrine of Spinoza in Letters to Herr Moses Mendelssohn can be found in F. H. Jacobi: The Main Philosophical Writings and the Novel Allwill, translated and edited by George di Giovanni.

4 Vallée, The Spinoza Conversations, $12 . \quad 5$ Ibid. 123. 
You know perhaps, and if you do not know I confide it to you here $s u b$ rosa, that Lessing in his final days was a firm Spinozist. It is conceivable that Lessing may have expressed this view to others; in that case it would be necessary for Mendelssohn, in the memorial he intends to dedicate to him, either to avoid certain matters totally or at least to treat them with the utmost caution. ${ }^{6}$

Mendelssohn took the bait, and asked for more information. In November of 1783, Jacobi sent Mendelssohn a long report of his conversation with Lessing. Jacobi reports that Lessing told him that "the orthodox concepts of divinity are no longer for me; I cannot stand them. Hen kai Pan! I know nought else." And to top it off, Lessing claimed, "If I am to call myself by anybody's name, then I know none better" [than the name of Spinoza]. ${ }^{7}$ A long correspondence between Jacobi and Mendelssohn ensued, finally published by Jacobi in Über die Lehre des Spinoza. Among other things, the book contains Jacobi's understanding of the "spirit of Spinozism," as well as his arguments that Spinozism is equivalent to atheism, and that all rationalism, including that of Leibniz, eventually dissolved into Spinozism. ${ }^{8}$

In understanding Spinozism, it is important to remember that Schleiermacher is directly responding to Jacobi, and that Jacobi espoused versions of key Leibnizian doctrines. Jacobi understood Leibniz as having thought of the monads as vinculum compositionis, ${ }^{9}$

6 Vallée, The Spinoza Conversations, 5. $\quad 7$ Ibid. 9-10.

8 For a more in-depth discussion of the Pantheism Controversy, see Frederick C. Beiser, The Fate of Reason: German Philosophy from Kant to Fichte, as well as George di Giovanni, Freedom and Religion in Kant and His Immediate Successors, especially pp. 137-51. Paul Franks also provides an excellent discussion of Jacobi's influence and the question of post-Kantian Spinozism in All or Nothing, 84-145.

9 In his February 1712 letter to Des Bosses, Leibniz notes the following regarding the vinculum substantiale: "If the vinculum substantiale of monads did not exist, all bodies, together with all of their qualities, would be nothing but well-founded phenomena, like a rainbow or an image in a mirror, in a word, continual dreams perfectly in agreement with one another, and in this alone would consist the reality of those phenomena." G. W. Leibniz, Philosophical Essays, 198-9. For Leibniz, the vinculum explains the underlying nature and per se unity of corporeal substance. The best, most nuanced discussion of the role of this idea in Leibniz's philosophy can be found in Robert M. Adams, Leibniz: Determinist, Theist, Idealist, 299-307. Adams, however, concludes that Leibniz "never had a deep personal commitment to the view that there are corporeal substances, one per se" (307). Jacobi, on the other hand, understood the vinculum as guaranteeing both the principle of individuality and of personhood: it is the principle of the indivisibility of the unity of the manifold, and he determined this 
that is, the monads supply a principle of the indivisible unity of the manifold. Jacobi called this principle the "I." This I "distinguishes itself from all experiences and representations" and provides unity to the manifold given through consciousness of the world. According to Jacobi "all truly real things are individuals or single things, and as such are (a) living essences, principles (b) perceptive and (c) active, and they are outside one another." ${ }^{10}$ He stressed the active character of these living principles, that is, their freedom, and he conceives of the individuals as spontaneously reacting to one another. At the same time, Jacobi stressed the community of all individuals: all the individuals reciprocally determine one another. ${ }^{11}$ Because of their nature, "the concepts of unity and plurality, of activity and passivity, of extension and succession" are innate in individuals. ${ }^{12}$ Jacobi also adopted the Leibnizian notion of the pre-established harmony. ${ }^{13}$

\section{THE EPISTEMOLOGICAL PROBLEM}

In the following passage cited by Schleiermacher, Jacobi comments upon both Leibniz and Spinoza:

Nevertheless, Bourget believed he had discovered a furthering of Spinozism, or rather of its spirit, in even this new system. Leibniz answered him: I do not see how you want to bring out Spinozism here. On the contrary, it is precisely through the monads that Spinozism is overcome. For so many monads, so many real substances or indestructible, and at once living mirrors of the universe, or concentric worlds, exist. Contrary to this, according to Spinoza, there can be only one single substance. Were there no monads, then Spinoza would be correct. All outside of God would be ignored, and would disappear as an accidental attribute, for the things would be lacking their

principle as the "I." On this point see Eilert Herms, Herkunft, Entfaltung, und erste Gestalt des Systems der Wissenschaften bei Schleiermacher, 129.

${ }^{10}$ F. H. Jacobi, Werke, Volume II, 261. All translations from Jacobi's Werke are my own.

11 Jacobi, Werke, $\mathrm{IV}_{1}, 225 \mathrm{ff} . \quad 12$ Jacobi, Werke, II, 261.

13 George di Giovanni provides an excellent discussion of Jacobi's philosophy in "The Unfinished Philosophy of Friedrich Heinrich Jacobi," the introductory chapter to F. H. Jacobi: The Main Philosophical Writings and the Novel Allwill. He also discusses Jacobi's philosophy in Freedom and Religion. 
own ground of endurance or substance, which is given through the monads. This is completely right. Spinozism can only be grasped with success from the point of view of its individuation, in which case then it must be replaced by either Leibniz's monads or the Eleatic acatalepsy. In his (Spinoza's) system the individua, or individual things, are yet so little as the Godhead itself, which brings forth the infinite from the infinite in an absolutely necessary way. But he gives no justification of the inner possibility of such individual things in the absolute continuum. He gives no account of their division and of the community of their effects, and this on account of an astonishing war of all against all bringing with it a fleeting individuality that unites, in a tangled way, all unity in and with the infinite. ${ }^{14}$ (KGA I.1, 547)

In both Spinozism and the Short Presentation, Schleiermacher proceeds to defend Spinoza, and argues that Leibniz's philosophy is not an improvement over that of Spinoza. The principal question at issue, according to Schleiermacher, is whether we have grounds for thinking that there exist individuals having their own ground of endurance or subsistence in themselves. ${ }^{15}$ Schleiermacher adopts the Kantian distinction between phenomena and noumena, and he does not deny that individuals appear as phenomena. What he denies is that there exist objects that in themselves are individuals and that have within them their own ground of endurance. He marshals several arguments for why we do not have good grounds for thinking that there are discrete individuals. In what follows I will discuss each of these.

14 All translations from Spinozism and the Short Presentation, which can be found in KGA I.1, are my own. All future references to these two pieces will be indicated by $K G A$ I.1 with page numbers following, and will be internal to the text.

15 Adams identifies another, related problem in assessing the relation of Leibniz to Spinoza. The question is whether "the world is something external or additional to God" (126). In his book Leibniz: Determinist, Theist, Idealist, Adams provides an account that is historically sensitive to Leibniz's changing views. The earlier Leibniz, writing in 1676, "flatly affirms the Spinozistic idea that finite things are only modes" (129). By 1688 Leibniz has, however, changed his views. In his paper "On the Abstract and the Concrete" (c.1688) Leibniz argues that there must be a genuine distinction between God and creatures, for God's reality is infinite, that of creatures is finite. Because the powers are distinct (one is infinite, the other finite), there must be two subjects to which these powers can be ascribed. As Adams notes: "We are left, I think, with the following answer to the question whether Leibniz's conception of God as ens perfectissimum has, inescapably, Spinozistic implications: it does not. The relation of the limited attributes of creatures to the absolute attributes of God is not the relation of mode to attribute, since they exclude each other from any one subject, by virtue of the negation involved in the creaturely attributes" (134). 
He first notes that two questions must be distinguished: first whether individual finite things have substance, and second, whether they are substances. He admits that all finite things have substance, but denies that they are substances (KGA I.1, 547). A thing may have substance insofar as the one substance grounding everything is its ground, or insofar as it is made up of a part of the universal substance. This however, does not mean that it is a substance. For something to be a genuine substance, it must have its own principle of endurance or subsistence separating it from other substances, that is, it must have its own principle of individuation. The first question, that of whether things have substance, has nothing to do with the principle of individuation itself, "for if it is granted that a thing A has something substantial in itself, it does not thereby follow, that, and to what degree, it is to be considered as a separate thing" (KGA I.1, 547-8). Schleiermacher contrasts Spinoza's understanding of how things possess substance with that of Leibniz: "the latter says: yes, the finite (extended) things have something substantial in them, namely the monads. The former says: yes, what is substantial in them is the being which is a part of the universal substance" (KGA I.1, 548). Schleiermacher argues that the problem with Leibniz's position, however, is that it provides us with no way of identifying the principle of individuation. Leibniz's idea of monads does not clarify "how that which I recognize through pure reason as substance is unified" (KGA, I.1, 548). In other words he fails to provide adequate criteria through which we can determine that something is an independent substance.

Schleiermacher assumes a thoroughly Kantian standpoint when he poses his question to Leibniz concerning the principle of individuation. Our continuously changing perceptions are "given to us as sensation and change of sensation" (KGA I.1, 549); moreover, the "whole world of sense is there in and through you" (KGA I.1, 550), that is, the world of sense is given to us in and through modifications of the mind. The question then becomes how the continual flux of perceptions can generate our everyday objective experience of tables and chairs. Leibniz's principles do not make clear to him "how and why I consider the objects given to me in outer experience as separate from one another, how I thereby come to combine into an objective unity its manifold, and on what it depends that I connect exactly this 
many and exactly this manifold?" (KGA I.1, 548). Although Leibniz has shown "how and that many substances are possible" (KGA I.1, 548 ) his positing of the monads remains a mere hypothesis. Schleiermacher asks,

But tell us something about how and why you distinguish the phenomena as separate objects. Does this distinction have to do with the one combination, so that you would know you have grasped precisely that which results from a monad connection through your representation? How might you know this? Or does it have to do with this: that just what you see as your object belongs to a common central monad? How do you know this then, and how have you achieved this knowledge of monads through which to separate the individuals from one another? (KGA I.1, 548)

In other words, Schleiermacher asks, how do we know that the activity of the understanding, in producing phenomenally distinct objects such as tables and chairs, actually hooks up with what are metaphysically real individuals, that is, individuals in themselves? Leibniz believed that we are in contact with God alone and that our knowledge of all other things derived from our relation to God. In $\$ 28$ of his Discourse on Metaphysics Leibniz notes that, "there is no external cause acting on us except God alone, and he alone communicates himself to us immediately in virtue of our continual dependence... It can then be said that God is our immediate external object and that we see all things by him." ${ }^{16}$ Leibniz explains our ability to know other monads through God's conservation of the ideas of such monads in us. It is likely this idea that Schleiermacher has in mind when he notes "just what you see as your object belongs to a common central monad." According to Leibniz, we know of other individuals and their states in virtue of the preestablished harmony: "But in simple substances the influence of one monad over another can only be ideal, and can only produce its effect through God's intervention, when in the ideas of God a monad rightly demands that God take it into account in regulating the others from the beginning of things" (Monadology, \$51). ${ }^{17}$ From the very

${ }^{16}$ Leibniz, Philosophical Essays, 59. On Schleiermacher's access to this text as well as to these ideas, see note 3, chapter 4, "The World is the Mirror of the Self." As I note in the introduction, it is only in 1797-8 that Schleiermacher comes to study the original Leibnizian texts.

17 Leibniz, Philosophical Essays, 219. 
beginning God harmonizes all monads and their states with one another, and it is through this harmony that our knowledge of other individuals is guaranteed. Schleiermacher complains that this way of understanding the matter, however, remains a mere hypothesis. If we begin with the fact of the continual flux of perceptions in inner sense, there is no way to know that the phenomenal individuals we experience map onto individual things in themselves. The "vinculum of the monads is something so completely unknown and undetermined" (KGA I.1, 548-9). Hence Schleiermacher concludes, "The most that one can admit is that, objectively, Leibniz solved the problem through a hypothesis, namely, of how individual things could be possible in the continuum of extension and of consciousness." However, Schleiermacher claims, Leibniz did not touch upon the corresponding subjective question: "through which effects of these things on us are we constrained to make this distinction in experience as well?” (KGA I.1, 548).

Schleiermacher takes what he understands as Kant's account of the "subjective ground of individuation" 18 as decisive, and notes that is something "of which we will all be in agreement, for hereafter no one can ground it validly to the exclusion of his system" (KGA I.1, 550). Schleiermacher thereby explains how we come to have the phenomenal experience of individuals that we do in terms of Kant's analogies of experience. These analogies provide an account of how and why the continuous change of perceptions given in inner sense must be interpreted in such a way that we think of phenomenal substances as (a) enduring, (b) changing in accordance with natural laws, and (c) existing simultaneously and in thoroughgoing interaction, or community, with one another. Schleiermacher notes that "According to your currently reigning mode of thinking, you say, in fact, that the application of the laws of the understanding makes experience out of these perceptions, and particularly the analogies of experience constrain you not only to combine the idea of a necessary connection between an earlier state and a later state with each change, but also to think of something real and persisting as grounding

18 When Schleiermacher speaks of the "subjective ground of individuation," he is referring to the phenomenal individuation of Kant's appearances. He takes this ground to be "subjective" insofar as phenomena are the result of the operations of the synthesis of the imagination. 
each sensation" (KGA I.1, 549). Kant's first analogy of experience stipulated that time determination requires us to posit the existence of a persisting substance underlying the changes of appearance. ${ }^{19}$ According to the second analogy, time determination also requires that we be able to provide an objective account of the succession of changes in an appearance. Such an account of the order of changes must be distinguishable from the order given in the apprehension of successive representations. Kant argues that in order for such an objective account to be possible, we must think of all alterations as occurring in accordance with the law of cause and effect. Lastly, Kant's third analogy stipulates that in order for us to be able to think that the sequence of our perceptions is grounded in an object, we must think of substances as in space and in thoroughgoing interaction, or community with one another. These three analogies, having to do with persistence, succession, and simultaneity, must be assumed if objective experience is to be possible, that is, if we are to be able to distinguish between our subjective apprehension of perceptions and the appearances as objects of experience.

Schleiermacher's point is that these analogies only give an account of phenomenal reality, that is, of how we must connect the representations given to us in sensation in order to arrive at objective experience. The analogies in no way guarantee that this phenomenal reality hooks up with the way things are in themselves. Hence he notes,

You may not claim that the ground of the plurality of substances in space lies in the plurality of substances in themselves, for this claim would contradict your remaining doctrine. Even less may you give this reason for your

\footnotetext{
19 This is because (a) we are aware of time only in and through the relation of the representations given in inner sense to one another; as such time cannot be perceived. (b) The representations given to inner sense are continuously changing and do not endure. (c) However, only through that which persists does duration acquire a magnitude. (d) Time itself cannot be that which endures, that is, time cannot be the changing thing underlying the changes since it is that through which the changes are to be measured. (e) What persists must therefore be the object itself, that is, the substance. (f) Hence, everything that changes can belong only to the way in which this substance or substances exist. (g) This further implies that because substance is the substratum of everything real and always remains the same, its quantity in nature can be neither increased nor destroyed. I provide a detailed analysis of Kant's first analogy and its relation to his refutation of idealism in my chapter "On Some Presumed Gaps in Kant's Refutation of Idealism" in Rameil (ed.), Metaphysik und Kritik.
} 
subjective perceptions of the plurality of finite substances (phenomena), since the whole world of sense is in and through you. How then does it come about that you reduce your perceptions to determinate objects, individuals? You answer that this stems from the original synthesis of the imagination, which gives unity to the manifold. Since by itself it does not brand each individual sensation as an individual, and yet also does not collect them all together under a single unity, what then is the ground of your operation? What justifies their separation? Thus, if for Leibniz individuation is explained only through a shaky hypothesis, and is thereby also not something solid and completely true, then for you it is something completely arbitrary, and yet belongs to that which you alone call real and certain.

(KGA I. 1, 549-50)

Schleiermacher here seems to be directly taking issue with Jacobi. He claims Jacobi cannot consistently affirm that the plurality of substances in space is grounded in the plurality of things in themselves, "for this claim would contradict your remaining doctrine." Jacobi did believe that phenomena were grounded in things in themselves. He did not, however, hold to the Kantian-like views Schleiermacher seems to be attributing to him, and which would pose difficulties for such a view.

To judge from what he says in Spinozism, it is unclear whether Schleiermacher was fully acquainted with Jacobi's doctrines at this point, or whether he misrepresents Jacobi's position as a rhetorical strategy. For example, he assumes that Jacobi agrees with him concerning how we arrive at the "subjective principle of individuation." In invoking the analogies to support this "subjective principle," it is clear that Schleiermacher has Kant's doctrine in mind, and Schleiermacher proceeds as if Jacobi must agree with Kant's critical idealism as Schleiermacher understands it. ${ }^{20}$ However, Jacobi's own doctrines were quite different from Kant's. Specifically, Jacobi adhered to a direct, unmediated realism. He denied that we arrived at the conclusion that things exist through any deductive process; he claimed there is an immediate connection between our conviction of the existence of things and our representations. This unmediated conviction of existence extends to both our own existence and to the existence of

20 Schleiermacher's discussion of the analogies as supporting the subjective principle of individuation is misleading, since for Kant the analogies of experience are conditions of the possibility of objective experience. 
things outside of us. We become aware of things outside of us "with the same certainly with which we become aware of ourselves." ${ }^{21}$ Not only do we arrive at the conviction of the existence of ourselves and of things outside of us in the same way, that is, without any mediation, we also arrive at both convictions simultaneously. According to Jacobi, we become aware of both our self-consciousness and things "in the same instant, in the same indivisible moment, without before or after, without any operation of the understanding, yes, without the conviction of the concept of cause and effect even remotely beginning in them." 22 In 1787 Jacobi wrote,

The thing brings just so much to the awareness of consciousness, as consciousness does to the awareness of the thing. I experience that I am, and that something is outside of me, in the same indivisible instant: and in this instant my soul is no more affected by the thing as it is by itself. No representation, no conclusion mediates this double revelation. Nothing enters the soul between the awareness of the real outside of it. Representations do not yet exist; they first appear afterwards in reflection, as shadows of things that were present. We can also always lead them back to the real from which they are taken and which they presuppose. We must thereby go back to the real each time if we wish to know whether they are true. $^{23}$

Jacobi, then, rejects Kant's analogies of experience, for these clearly involve the activity of the understanding. Moreover, Kant's refutation of idealism, coming as it does after the analogies in the second edition of the first Critique, presupposes the analogies. In his refutation of idealism Kant sought to show that awareness of the time determination of inner experience presupposes outer experience, that is, experience of things outside the self. Both Kant and Jacobi are in agreement that awareness of the self is intrinsically tied up with awareness of things outside the self. They disagree, however, on how this comes about. According to Kant, the activity of the understanding is required in order to distinguish objective experience from my merely subjective apprehensions. Self-consciousness and the distinction between self and world thereby depend upon the activity of the understanding. According to Jacobi, on the other hand,

\footnotetext{
${ }^{21}$ Jacobi, Werke, II, 143; IV $1,211.22$ Jacobi, Werke, II, 176.
}

23 Ibid. 175. 
we have a direct, unmediated awareness of both self and world. No representations and no activity of the understanding mediate this awareness. ${ }^{24}$ Representations are themselves mere shadows of this immediate, direct awareness. ${ }^{25}$

Schleiermacher's argumentative strategy is to assume that Jacobi must agree that what we have to work with is a manifold of sensations on which the understanding must operate in order for objective

24 In Freedom and Religion, di Giovanni provides a useful discussion of Jacobi's attempt to discover "the right formula for representing how an experiencing subject, in becoming aware of himself, equally becomes conscious of the presence of an external world." At the heart of this formula is Jacobi's insight that fundamental awareness of the self is given in action. The self knows itself immediately in the feeling of power that the subject has of itself when it acts. As such, Jacobi analyzes a fundamental, existential dimension of human being in the world. His formula representing how experience is possible, found in his 1787 book entitled David Hume on Faith, or Idealism and Realism, a Dialogue is summarized by di Giovanni as follows: "(1) Selfawareness originates in a subject's feeling of power. (2) This feeling immediately implicates the presence for the subject of an external something that exists in itself and interferes with the felt power, but at the same time provides the feeling with a reality check. (3) Representation is called into play as the reflective attempt on the part of the subject to sort out the difference between his own self and the external things resisting his power" (83).

25 Schleiermacher's notes on Jacobi's work, from about the same period-17934 - show that he is aware of Jacobi's direct realism and his arguments for it. Schleiermacher copied the following from Jacobi's David Hume über den Glauben oder Idealismus und Realismus (1787): "Therefore, however, as a realist I must say: all knowledge could come completely from belief alone, since things must be given to me before I am in a position to recognize relations" (KGA I.1, 595). Schleiermacher also copies Jacobi's arguments that certainty of outer things must be an unmediated certainty. The Kantian philosophers, according to Jacobi, are merely "empirical realists" but they are not "genuine realists." And he continues: "The validity of empirical evidence is just that which is in question. That things appear to us as outside of us requires no proof. That, however, these things are thereby not pure appearances in us, not mere determinations of our own self and thereby nothing as representations of something outside us, but rather that they are representations in us that relate to beings outside us really existing in themselves and that are taken from them-against this not only can doubts arise, but it is often the case that the strongest understanding cannot overcome these doubts through rational grounds. Your unmediated certainty of outer things would thereby be a blind certainty according to the analogy of my belief" (KGA I.1, 596). In Spinozism Schleiermacher makes no mention of this stance, namely of the possibility of a direct, unmediated realism, and of Jacobi's claim that we have this direct access to things through belief. If he had been aware of this at this point, one would expect that he would have dealt with it when he asked the question of how it is possible to distinguish between inner sense and outer appearances. It therefore seems to me that he must have written Spinozism before he began to think about Jacobi's direct realism. 
experience to be possible. Schleiermacher's question to Jacobi, "How then does it come about that you reduce your perceptions to determinate objects, individuals?" (KGA I.1, 550) only makes sense on the assumption that Jacobi had adopted key elements of Kant's transcendental idealism. It is clear, however, that Jacobi rejected most of the critical philosophy. In its place was his direct realism. Hence the question of how we can be certain that our phenomenal experience of individuals is grounded in things as they are in themselves is not really an issue for him. This is because according to Jacobi's system, we never really begin with phenomenal experience. We begin with a direct awareness of the things as they are in themselves. Just like our representations, phenomena are mere shadows of that which we already directly apprehend. The question of how we can move from our phenomenal awareness of individuals to individuals as they are in themselves does not, then, cut against his system.

Contra Jacobi's position, Schleiermacher affirms "our whole manner of separating things into individuals is in no way an effect of this whole from the outside, but is rather an inner action. It is thereby either determined in accordance with our necessary laws grounded in representations, or is a wholly blind instinct. Leibniz must thereby throw his lot in with Kant..." (KGA I.1, 552). Schleiermacher affirms that the manifold of sensation that comes to us from the outside does not bring with it its own interpretation. What is given to us through the senses is "sensation and change of sensation." This explains why our "perceptions are not continuous" (KGA I.1, 549), that is, the sensations we experience are continuously in flux. Moreover, since we first begin with our subjective apprehension of these sensations, Schleiermacher asks the Kantian question "how would you have arrived at the distinction between inner sense and outer intuitions?" (KGA I.1, 552). Kant's answer to this question is the analogies of experience. As we have noted above, Schleiermacher refers to these as well and is in agreement with Kant on this point.

How is the distinction between self and outer objects possible? Given that our "perceptions are not continuous," we never have direct access to that which underlies the continually changing determinations of the appearance, for we do not have a continuous perception of the underlying substrate. We merely infer it. For that matter, we have no access to a permanent representation of the self that 
endures throughout the change in its representations (considered as its determinations). And this inference to substance as that which underlies the changing determinations of the thing is a result of the application of the necessary laws of the understanding to what is given in sensation. It is therefore the result of our own activity and is not merely given to us from the outside. In all objective knowledge of the appearances, the synthesis of the imagination is continuously at work. For example, how the visual field is integrated with the auditory and tactile fields is the work of this synthesis. The perceptions that come to us from the visual field do not, in themselves, contain those of the auditory or tactile fields. Schleiermacher notes, "You separate the thing, viewed as chaos, in several objects in accordance with the different modes of perception. It is at least difficult to grasp how the imagination should thereby come to connect that into a unity which does not allow itself to be taken together, because it does not grasp it [viz., the visual field] in another [viz., the tactile field], and they cannot be made to follow one another" (KGA I.1, 553). What Schleiermacher calls chaos is the uninterpreted manifold of perception. Moreover, he argues, not only are the perceptual fields, insofar as they are purely given, not integrated with one another, but the data from each field also require the activity of the understanding in order for this data to make sense. Schleiermacher affirms, "the eye in itself is not skilled to distinguish objects. It shows the unpracticed seer everything on a single plane and distinguishes only colors. And if we now need it principally for this [distinguishing objects] this then happens, so to speak, only through a shortened kind of calculation, the rules of which we could only have come by through long practice. Even so little touch. It distinguishes only degrees of hardness and fluidity" (KGA I.1, 553). The upshot of all of this is that, contrary to Jacobi's views, Schleiermacher believes we have no unmediated access to things. We have immediate access to our perceptual states, and only given the activity of the synthesis of the imagination on the manifold of sense do we come to the ordinary world of tables and chairs. But if this is the case, what guarantee do we have that the phenomenal world of tables and chairs actually maps onto things in themselves?

Schleiermacher's next argument has to do with the nature of phenomenal individuals. He argues that whatever understanding we come to have of such individuals is only an approximate, 
probable concept. From the phenomenal point of view, individuals are determinate masses. He defines a determinate mass as "the point of unity of several of these modifications at each moment." The modifications he has in mind are those of "movement and rest, representation and desire" (KGA I.1, 551; cf. 574). It is because we believe we can identify such a point of unity of these modifications that we call something an individual. But can such a point of unity really be identified? The problem is that of the continuous change in state of the appearances. He tells us, "no particle can remain completely the same throughout because of continuous change. Rather, in part the same mass takes on different determinations, and in part the same determinations pass over into a different mass. Yes, I cannot even determine which mass is to be regarded as an individual, for this mass is also divisible in thought" (KGA I.1, 551). The way that Schleiermacher is thinking of "mass" is in terms of a kind of substrate, that is, mass seems to be an extended kind of stuff that is the bearer of the properties, or determinations of a thing. However, we never have a continuous perception of such a mass. We perceive only its changing states. But this means that the substratum, shorn of all of its properties, is not continuously identifiable. It is therefore unclear how Schleiermacher can assert that different determinations pass over into the same mass, and that the same determinations pass over into different masses. How could we possibly know that something is the same mass, or is a different mass apart from its determinations? If however, the substratum is thought of as extended, then what remains continuously identifiable are particular portions of space.

This way of thinking echoes the theory Plato puts forward in the Timaeus, and Schleiermacher is very likely referring to it here through his reference to Plato. In the Timaeus Plato had asked, "Do all these things of which we always say that each of them is something 'by itself' really exist?" Plato tells us that that which is perceived by the senses is "constantly borne along, now coming to be in a certain place and then perishing out of it." Space, one the other hand, "exists always and cannot be destroyed. It provides a fixed state for all things that come to be." ${ }^{26}$ On this theory, space is the only continuously identifiable substrate, and all coming to be and perishing are its

26 Plato, Timaeus, translated by Donald J. Zeyl, in Plato: Complete Works 1255. 
determinations. Space is, as such, the receptacle that "receives into itself" all becoming. Plato calls belief in the existence of things "by themselves" the subject matter of true opinion. It is significant that that is exactly what Schleiermacher calls these here-he tells us that "Alone, as is said, the practical use confirms that the concept [of the individual] has no other validity than that of an approximate, probable concept, and that everything that touches upon it can only be, as Plato says, a $\delta o \xi \alpha v a \lambda \eta \theta \eta \nu$ " (KGA I.1, 551). On such a view, the only real individual is the extended, material substrate; in itself it is indeterminate and one. It is the receptacle for all becoming. ${ }^{27}$ In the Short Presentation of the Spinozistic System, Schleiermacher claims that it is the continual coming into being and perishing of things, that is, their continual flux, that led Spinoza to posit the unity and eternity of the one substance (KGA I.1, 564, 567). At this juncture Schleiermacher seems to be reading Spinoza in light of Plato.

The extended character of this material substrate means that it is divisible. As noted above, he argues that "Yes, I cannot even determine which mass is to be regarded as an individual, for this mass is also divisible in thought." Given its divisibility, and given the fact that all the smaller particles out of which such a mass is composed "are not perfectly homogenous with the whole,... this [whole] will therefore

27 In A Study of Spinoza's Ethics, Jonathan Bennet interprets Spinoza as putting forward a similar theory. He notes “... at Spinoza's most basic metaphysical level there are no occupants, but only space, its different regions altering in orderly ways." In Behind the Geometrical Method, Edwin Curley characterizes this theory, which he rejects as a proper interpretation of Spinoza, in the following way: "We might argue, for example, that for Spinoza, as for Descartes, ordinary physical objects are best viewed as larger or smaller portions of one continuous physical object, portions distinguishable from their neighbors only because they happen for a time to be qualitatively different. Ultimately there is just one extended thing, the whole of the physical universe (Descartes's "body in general"). The existence of lesser extended things just consists in the one extended thing's being qualified in certain ways at certain times and places. To say that the piece of wax is a mode of the one substance is to say that the one extended thing has certain properties at certain places and times..." (31-2). It is important to note, however, that Schleiermacher did not ultimately read Spinoza in this way. He recognized the significance of the fact that for Spinoza extension and thought are mere modes, or expressions of the one substance. As such, while space is the only continuously identifiable substrate that takes on changing determinations, it by no means follows that it, and the things that come to be and pass away in it, are to be completely identified with the absolute. They are, rather, merely an expression of it. 
not be the point of unification for all [the particles] in the same way" (KGA I.1, 551). ${ }^{28}$ An extended thing that we think of as an individual may be composed of different particles that are themselves the "points of unification" of different forces. Schleiermacher seems to be asking, why then should we call these composites individuals? Are such composites really individuals, or merely aggregates? On what grounds do we distinguish individuals from mere aggregates? This is the upshot of Schleiermacher's argument when he writes:

You call your body an individual although many parts are completely foreign to it and do not have any part in its nature. You attribute an identity to it even though its mass, as well as its character, change almost hourly. You do not call the air in the room an individual, even though, on account of its local connectedness, it undergoes a completely different series of changes than what is separate from it, which then at the moment of separation already ceases to be homogeneous with it. For example, you do not call several pieces of wood on a heap an individual, even though they are completely one with one another in relation to motion and rest. For the most part, you thereby apply the concept only in a one-sided way and think that you are right. Yet you must necessarily be aware that the concept is imperfect.

(KGA I.1, 551-2)

Moreover, Schleiermacher argues, things undergo constant change. If so, then which determinations are we to think of as essential in order for a thing to preserve its identity? Just how many changes in determinations can a thing undergo before it loses its identity? In the end, the whole concept of the individual "falls apart little by little into those parts to which, together, a proper series of changes can be attributed. This is thereby the sole canon according to which your idea of individuals - mediated in part through sight, mediated in part through touch-realizes itself" (KGA I.1, 553-4). In other words, what we think of as an individual amounts to a series of extended parts that together undergo a "proper" series of changes. But just how do we identify this "proper" series of changes? How are we to grasp the concept that allows us to unite these parts and their

28 The Short Presentation contains a related argument. He claims that "the plurality of phenomena" cannot relate to a plurality of noumena. This is because "we can divide a physical individual in many parts. Were each individual in the world of sense to correspond to one in the intelligible world, then we must be in a position to increase the number of things in themselves" (KGA I.1, 574). 
changes such that we think of them as an individual? Such a concept, Schleiermacher argues, can only be an approximate, probable concept. Even in its "practical use" it is not a "self-contained and perfectly delimited concept."

\section{THE METAPHYSICAL PROBLEM}

So far, we have examined Schleiermacher's epistemological objection to the positing of individuals: we have no access to the vinculum of the monads-that in virtue each monad has its per se unity, and in virtue of which we can distinguish one from another. We have access only to phenomena. As such we have no way of knowing what constitutes genuine individuals; this was the principle flaw in Leibniz's system. Leibniz's positing of individuals remained a mere hypothesis. A long, remarkable passage towards the beginning of Spinozismus provides insight into Schleiermacher's metaphysics and why he does not believe that there are substantial individuals. Jacobi had written: "What we call sequence or duration is at bottom pure illusion. For since the real effect is given at once with its complete real cause, it is differentiated from it only through the representation [der Vorstellung nach]. Hence sequence and duration must be, in truth, only a certain form and manner of viewing the manifold in the infinite" (KGA I.1, 526). In response to this Schleiermacher comments:

These words only first lead me to a certain materialistic view, in which the Spinozistic relation of the noumenon to the phenomenon almost fuses with the Kantian. This view can also be attributed to the Leibnizian. Let us suppose a common noumenon lies at the ground of each succession of appearances, through which we believe we hold an individual in view. If one also wants to assume only some agreement with the appearance of the thing, then this noumenon, considered in itself, must contain not only everything essential that the appearances in the series have in common with each other, but also that through which each member distinguishes itself from the others. Therefore, a being that should represent or view this thing in itself as one, without duration and succession, must therein at once perceive the preformed seed of all those appearances, the ground of all those relations of things to others from which the appearances develop themselves for us. Naturally, however, such a being must have a faculty of representation 
different from our own. It need not be bound to such a limited unity in the connection of the manifold. This is because, since it [the manifold] contains parts that we cannot think of in one [representation], this unity would not be in that representation. For instance, a noumenon lies at the ground of the seed and all its development up to the maturity of the tree. Such a being would already see in the seed the whole tree and everything that lay in between, and all that would be one to it. Because it must relate to one being, we could think of all that is coincidentally different, which opposes itself because of its relation to a concept, not as within one another, but outside one another, [yet] in accordance with each other. In this way the whole expresses itself to us only in a series of appearances, in which all is together, which may be together only for our faculty of representation, and all is separate, which must be separate as a consequence of the same. I believe that in this presentation nothing is contained that contradicts the Kantian view of things... If a noumenon should be the ground of the whole series of appearances from seed to tree, then this series may not end here, it must extend itself to all previous trees and seeds and those that follow, and because the mechanical and chemical changes in the thing, and the ground of their relation to others, must be just so well preformed as the organic, which are so precisely interconnected with it, then this series must extend throughout the whole world of sense, and we thereby come once more to the Spinozistic relation. (KGA I.1, 526-7)

Here Schleiermacher makes use of two different ways in which noumena, or things in themselves, function in Kant's philosophy. For Kant, appearances result from the application of the categories, or concepts of the understanding, to the manifold of sensible intuition. This has two implications regarding the relation between appearances and things in themselves that stand in tension with one another. First, the concept of an appearance implies the idea of a thing in itself. In the A edition of the Critique of Pure Reason, Kant noted, "appearance can be nothing for itself and outside our mode of representation. Thus, if there is not to be a constant circle, the word 'appearance' must already indicate a relation to something the immediate representation of which is, to be sure, sensible, but which in itself, without this constitution of our sensibility (on which the form of intuition is grounded), must be something, i.e. an object independent of sensibility" (KRV A251-2). An appearance implies something that appears. The appearance and the thing in itself are not two things, but are, rather, the same thing considered in different ways in transcendental 
reflection. The thing in itself just is that which appears when we attempt to think the latter in abstraction from how it must appear to us given our constitution. The appearance just is the thing in itself insofar as the latter presents itself to us, given "the constitution of our sensibility." In other words, the appearance and the thing in itself are the same thing considered from two points of view.

Nevertheless, Kant also spoke of appearances as being grounded in, or having their basis in, things in themselves. After all, they are given to us in sensation, and it is through sensation that we are affected by an "unknown something." In the Prolegomena Kant claims, "And we indeed, rightly considering objects of sense as mere appearances, confess thereby that they are based upon a thing in itself, though we know not this thing as it is in itself but only know its appearances, namely, the way in which our senses are affected by this unknown something. The understanding, therefore, by assuming appearances, grants the existence of things in themselves also..."29 This is the second way in which we can think of the relation between the appearances and things in themselves. However, this way of understanding this relation tempts us to think that things in themselves and appearances are two distinct things. We can be led to think of the former as the cause or ground of the appearances, and of the appearances as their effects, where ground and effect somehow stand "outside" one another. Clearly, there are tensions between both ways of understanding the thing in itself. Both are indisputably found in Kant's text. ${ }^{30}$ And Schleiermacher refers to both in his analysis.

The beginning of the passage clearly begins with the second view of this relation: "a common noumenon lies at the ground of each succession of appearances." However, Schleiermacher's argument depends in large part on his analysis of the distinct character of our mode of representation through which appearances are given to us. Appearances are given to us successively. For instance, when I view any object, such as a house, I first grasp one aspect of it, let us say the front, and then as I circle around it I apprehend the side and the back. I grasp the object through successive apprehensions. Through

29 Immanuel Kant, Prolegomena to any Future Metaphysics, [314-15].

30 For a discussion of the problem of the relation of things in themselves to appearances, see Henry E. Allison, Kant's Transcendental Idealism: An Interpretation and Defense, in particular the chapter "The Thing in Itself and the Problem of Affection." 
them different aspects of the thing are revealed to me. The whole object is not given to me all at once. Furthermore, our very thinking is discursive; we first think one representation and then another. Hence what we are given through our successive apprehensions is a series of successive appearances. That we think of things as enduring (duration) throughout the states of their changes (succession) is a consequence of this mode of representation, together with the possibility of objective experience. As a result of our mode of apprehending what is given to us in sensation, the manifold of intuition contains parts that cannot be given all at once in a single representation. In other words, those things that are "coincidentally different" in our apprehension of the manifold are given "not as within one another, but outside one another." As such, given our mode of representation, "the whole expresses itself to us only in a series of appearances, in which all is together which may only be together for our faculty of representation, and all is separate, which must be separate as a consequence of the same." Were we to abstract from our mode of representation, we might imagine how another being without our limitations would think what we must apprehend successively. Such a being would "have a faculty of representation different from our own." A being that can represent the thing in itself would view it as "one, without duration and succession," that is, it would represent all of it at once, in a single intellectual intuition. As such it would view "the preformed seed of all those appearances, the ground of all those relations of things to others from which the appearances develop themselves."

This passage from Spinozism can easily lead us to conclude that Schleiermacher understands the noumena and the appearances to be one and the same thing, viewed from two points of view. Schleiermacher does not speak of the noumenon as something different from the appearances. There are not two things or two worlds, the world of noumena and the world of phenomena. The noumenon does not stand outside the appearances, acting as their cause. It is true that Schleiermacher speaks of the noumenon as the ground of the appearances. But such talk of the noumenon as ground need not commit him to thinking of the two as constituting two worlds. The noumenon grounds phenomena only in the sense that, were we to be capable of an intellectual intuition, we would see that everything 
that appears phenomenally is already contained in the noumenon. God, as "ground" of the world does not stand outside of the appearances. This, of course, rules out the theistic vision in which God is understood as different from the world, as existing independently of it, and creating it "out of nothing." Schleiermacher's reading of Spinoza also seems to rule out panentheism. In panentheism, there is a distinction between God and world, but the world is "in" God. Still, on this view God is yet more than the world. What Schleiermacher seems to espouse here, however, is more pantheistic in nature. Insofar as Schleiermacher puts forward a double aspect view of the relation of noumena to phenomena, the view coheres with a thoroughgoing identification of God and world.

Spinoza's philosophy contains a related point, and no doubt this is one of the main reasons that Schleiermacher believed that the two philosophers were saying essentially the same thing. In proposition 18 of the Ethics, Spinoza claims, "God is the immanent, not the transitive cause of all things." A transitive cause stands outside of its effect, that is, the effect lies beyond the cause. Not so with an immanent cause. The effect of an immanent cause cannot even be conceived apart from it. As Spinoza notes in demonstrating this proposition, "Everything that is, is in God, and must be conceived through God." Moreover, Spinoza claims, "outside of God there can be no substance, that is, a thing which is in itself outside God." ${ }^{11}$ Insofar as God is an "immanent" cause there is an important sense in which God cannot be distinguished from the world, that is, nature is not a substance independent of God. The demonstration of Spinoza's Proposition 28, reproduced in its entirety in Jacobi's text and copied by Schleiermacher, contains similar claims. Its concluding lines affirm, "But all things that are, are in God, and so depend on God that they can neither be nor be conceived without him." 32 Schleiermacher adopts this understanding of the way that God relates to the world. He notes, "The infinite thing does not bring forth finite things and what belongs to them in a transitive way, not insofar as one is destroyed by the other, but rather only insofar as all belong to the eternal, unchangeable being" (KGA I.1, 529). The question, of course, still

31 Benedict de Spinoza, A Spinoza Reader: the Ethics and Other Works, 100.

32 Ibid. 104; cf. KGA I.1, 514. 
remains whether God completely exhausts God-self in nature, so that God and nature can be completely identified. ${ }^{33}$ Jacobi certainly understood Spinoza in this way, as is attested by the sixth paragraph of his forty-four paragraphs describing Spinoza's system. There he notes that "Therefore, the finite is in the infinite, so that the embodiment of all finite things is one and the same with the infinite thing, as in each moment it encompasses the whole of eternity, past and future in the same way" (KGA I.1, 514-15). Schleiermacher is working with this interpretation of Spinoza. And in light of this interpretation, it makes eminent sense to think of God and world as identical, only viewed from two different points of view. ${ }^{34}$

Schleiermacher argues that the view he puts forward here "can also be attributed to the Leibnizian" (KGA I.1, 526). What can he possibly mean here? He later notes, in agreement with Jacobi, that the Leibnizian position-when understood correctly-must ultimately dissolve into Spinozism. There he claims, "Now admittedly this personal God is not the cause of the world, and I have, after all, clearly shown that Leibniz, too, must arrive at such an idea of the deity" (KGA I.1, 532). In other words, he argues that given Leibniz's presuppositions, Leibniz cannot consistently hold to a creatio ex nihilo, and Leibniz's position is ultimately non-theistic. In $\$ 36$ of the Monadology Leibniz had noted "there is an infinity of past and present shapes and motions that enter into the efficient cause of my present writing, and there is an infinity of small inclinations and dispositions of my soul, present and past, that enter into its final cause." 35 This means that the

${ }^{33}$ Curley, in particular, questions whether a careful reading of Spinoza warrants an identification of the one substance with the whole of nature. He refers to Letter 43 , and notes "Spinoza is in fact contending, against Velthuysen, that his having said that all things emanate necessarily from the nature of God does not commit him to holding that the universe is God. I take this letter to be a clear rejection of that kind of pantheism." Behind the Geometrical Method, pp. 36ff, 149, n. 52.

${ }^{34}$ Paul Franks characterizes this move as one common to the German Idealists: "When they reject Kant's Two Essences view, the German idealists adopt what is in effect a Two Aspects view: the empirical aspect of a thing corresponds to the way in which a thing's being as it is, is ground in its relations to other things within the totality; the transcendental aspect of a thing corresponds to the way in which a thing's being as it is, is grounded in its relation to the totality and ultimately to the totality's absolute first principle. On this view, there is one world, understandable in two ways, or from two standpoints" Paul W. Franks, All or Nothing, 145.

35 Leibniz, Philosophical Essays, 217. 
ultimate ground of the state of any thing is completely determined by causes lying outside of it, causes that go back to infinity. However, Leibniz argues, if such efficient causes go back into infinity, we cannot give a sufficient reason for the state of anything unless we look outside the infinite series of conditioned beings. In $\$ 37$ he claims, "It must be the case that the sufficient or ultimate reason is outside the sequence or series of this multiplicity of contingencies, however infinite it may be." ${ }^{36}$ And in $\$ 38$, Leibniz continues, "And this is why the ultimate reason of things must be in a necessary substance in which the diversity of changes is only eminent, as in its source."37 The sufficient reason for the infinite series of conditioned beings lies eminently in God.

Why does Schleiermacher believe this leads to Spinozism? There are two reasons, both intimately related. First, if the state of each thing depends upon an infinite series of efficient causes, and if, moreover, this state itself determines all future states onto infinity, then there is a sense in which this state of the thing cannot be conceived through itself, since it stands in interdependence with all other elements in the series that lie outside of it. It can only be completely conceived through the whole world system, the elements of which mutually determine each other, and which thereby determine it. But since this system is infinite, it can only find its sufficient reason in God, who stands outside the series and contains all determinations of what occurs in the world only eminently. As such, the state of a thing cannot be conceived through itself; it can ultimately only be completely grasped (in terms of its sufficient reason) in relation to the infinite series of all finite things and in relation to the One that contains this series eminently. Second, given the fact that things are continuously coming into being and passing away (and changing into one another), what is the principle of individuation through which we are to mark off the beginning of one individual and the end of another? There is only one continuously identifiable substrate that takes on changing determinations, namely extension itself, which Schleiermacher conceives of in an organic sense. Hence, Schleiermacher notes, given the "alternating bringing forth and destruction of the organic parts of its 
extent [the extent of the world soul]," "finite individuals ... are not absolute." We therefore have, "once again, Spinozism.”

A similar kind of reasoning lies behind Schleiermacher's claim that "If a noumenon should be the ground of the whole series of appearances from seed to tree, then this series may not end here, it must extend itself to all previous trees and seeds and those that follow... This series must extend throughout the whole world of sense, and we thereby come once more to the Spinozistic relation." If the tree stands in complete interdependence with the series of events that lie outside of it, on what grounds do I mark off the noumenal ground of the tree from the noumenal grounds of all other things that I think are different from the tree, but upon which the coming to be of the tree depended? Moreover, in thinking of the noumenal ground of this tree, I must think of the whole series and its relation to God, which contains this series eminently. But I must think of the same series and its relation to God when I try to give a sufficient reason for another tree. The sufficient reason, and hence the noumenal ground of both trees, is the same. If the same noumenon grounds this tree and a future tree, on what grounds can I provide a noumenal distinction between the two trees? It is these kinds of considerations that lead Schleiermacher to affirm the Spinozistic idea that there is only one substance. ${ }^{38}$

Whereas in Spinozism Schleiermacher attempts to work out a view consistent with both Kant and Spinoza, in his Short Presentation Schleiermacher focuses on the differences between the two. He notes, "It cannot be claimed straight out, that the infinite thing relates to the

${ }^{38}$ For an excellent discussion of similar and related problems and how they drive post-Kantian Spinozism, see Franks, All or Nothing, in particular chapter two. Franks identifies what he calls Holistic Monism, a version of German Idealism that he argues is incompatible with one of Kant's fundamental commitments (namely that there are many noumenal agents). Two important characteristics of philosophical systems that embody holistic monism are the following: First, "the Holistic requirement is that, in an adequate philosophical system, empirical items must be such that all their properties are determinable only within the context of a totality composed of other items and their properties." Second, "the Monistic requirement is that, in an adequate philosophical system, the absolute first principle must be immanent within the aforementioned totality, as its principle of unity" (85). Both requirements follow from Spinoza's understanding of substance as that which can be conceived through itself, that is, that which requires nothing outside of itself for its intelligibility. 
finite in the same way in Spinoza as in Kant. For otherwise Spinoza would have had to discover the critical philosophy before Kant" (KGA I.1, 573). Moreover, he grants that from the standpoint of the critical philosophy, nothing can be said about things in themselves. Critical idealism could not "presume to go further" and to attribute to the noumenon "a positive unity and infinity." Of this "it could know nothing" (KGA I.1, 574). He is aware of the critical distinction between logical grounds and real grounds, and defends Spinoza from the accusation that he has mixed up the two (KGA I.1, 564-5). He notes that he himself had been tempted to think that Spinoza had made this mistake. He concludes, however, that Spinoza came to the conclusion that "there must be an infinite thing, in which everything finite exists," because all things are in flux, and no existence can be attributed to such things when they are considered in themselves (KGA I.1, 564-5); he thereby claims that Spinoza does not conclude to the existence of an infinite thing through a confusion of logical and real grounds. How Schleiermacher arrives at this conclusion remains unclear.

Schleiermacher's own argument concerning the noumenal ground of the tree, discussed above, does seem to ignore the distinction between logical and real grounds. As Kant had noted, it is "evident beyond all possibility of doubt, that if the conditioned is given, a regress in the series of all its conditions is set as a task". One must, however, distinguish between logical and real grounds. A logical ground has to do with propositions. It requires that if a given proposition is posited, we must also assume that all its conditions or premises are presupposed. This is "simply the logical requirement that we should have adequate premises for any given conclusion" (KRV A500/B529). In the case of states of affairs, however, we move from some actual, conditioned state of affairs, to another state of affairs that conditions it. According to Kant, however, this search for conditions is an "empirical synthesis." In an empirical synthesis, the conditions are only accessible through the activity of the synthesis itself. Given that what is given in empirical intuition must conform to the forms of intuition, space and time, and that what can be given through these are mere relations, ${ }^{39}$ it is impossible for the

39 Critique of Pure Reason, в 66-7. 
unconditioned (itself not conditioned by its relation to anything else) to be given in intuition. Moreover, the contribution of the subject in the activity of this synthesis cannot be ignored. ${ }^{40}$ This means that the imperative to search for the conditions for any given conditioned is only set as a regulative task. Since the elements of the synthesis must always be given to us successively through the forms of intuition, we cannot assume that once the conditioned is posited, all of the conditions are given along with it. Schleiermacher's argument regarding the noumenal ground of the tree, however, seems to ignore just this distinction. He assumes that we can inquire into the sufficient ground of each appearance, and thereby concludes that such a ground can only be grasped completely in terms of the whole series of appearances (the whole of the world) as well as in terms of what contains this series eminently. Hence he believes that once the conditioned appearance is given, we must assume that all of its conditions (the world as a whole, and God as its ground) is also given. Only in this way can he move beyond Kant's affirmation of the unknowable character of things in themselves and affirm that because the same ground conditions all appearances, there can be only one noumenon.

Significantly, Kant had recognized that if space and time are thought of as features of things in themselves, Spinozism results. In the Critique of Practical Reason he argued that

if this ideality of time and space is not assumed, only Spinozism remains, in which space and time are essential determinations of the original being itself, while the things dependent upon it (ourselves, therefore, included) are not substances but merely accidents inhering in it. For if these things exist only as its effects in time, which would then be the condition of their existence itself, the actions of these beings would have to be merely its actions, which it performs anywhere and at any time. Spinozism, therefore, in spite of the absurdity of its basic idea, argues far more cogently than the creation theory can... (KprV 5:101-2)

What is given in intuition is always conditioned; it always stands in relation to something else and cannot be grasped outside of

${ }^{40}$ On this point, see Henry Allison's discussion in Kant's Transcendental Idealism, 53ff. See also Michelle Grier, Kant's Doctrine of Transcendental Illusion, in particular chapters three and four. 
this relation. If we are transcendental realists and think that space and time are features of things in themselves, then we must also assume that things in themselves can be completely described in terms of these spatial and temporal features, which, however, only exhibit things as they stand in relation to one another. If things in themselves are spatial and temporal, their properties, too, are intrinsically relational. But if all we have are things whose properties are all intrinsically relational (such that each thing and its properties cannot be grasped outside of its relation to other things), there can then be no plurality of genuine substances, each of which must contain the principle of its own activity within itself if it is to be a substance. Instead, the action of all phenomenal beings must be thought of as the temporal effects of a single, unconditioned being, and hence we come back to the Spinozistic relation. While Schleiermacher adopts the Kantian view of the ideality of space and time, in Spinozism he does not address why Kant believed that transcendental idealism blocks the Spinozistic conclusion. He demonstrates more awareness of this in the Short Presentation where he notes that while "Spinoza likewise proceeds from the universal problem, to find the unconditioned from the conditioned... Kant at least allows the thought of an unconditioned outside of the series of appearances. Spinoza thought no other unconditioned is possible than the complete totality of the conditioned" (KGA I.1, 574).

Schleiermacher's preferred argument for the claim that there is only one thing that really exists has to do with the constant flux of appearances. In a remarkable passage in Spinozism Schleiermacher affirms:

My sensualization is not taken from the object of space, but from time. However, the application is easy and natural. The actual true and real in the soul is the feeling of Being, the immediate concept, as Spinoza calls it. This, however, can never be perceived. Only individual concepts and expressions of the will can be perceived, and apart from these, there exists nothing else in the soul at any moment of time. Can one for this reason say that individual concepts have their distinct, individual being? No, nothing actually exists except the feeling of Being: the immediate concept. Individual concepts are only its revelations. Can one say that the immediate concept exists only as 
thinking in another? By no means. The immediate concept is the actual, essential ground of the soul. All those individual concepts inhere in its modes (understanding and will). Yet admittedly, one must not go on from this to say that the immediate concept is the sum of the individual concepts.

(KGA I.1, 535)

Schleiermacher does not proceed from the problem of the constant flux of appearances in space (as does Plato), but rather from the successive character of the apprehensions given to the understanding. Hence he notes that his own argument is "not taken from the object of space, but from time." Schleiermacher affirms, along with Kant, that time is the form of inner sense, that is, it is given in and through the way that the self successively apprehends the manifold. ${ }^{41}$ And it is from the successive and fleeting character of these apprehensions that Schleiermacher proceeds to build his argument. These are what consciousness perceives, although they have no genuine subsistence in themselves, and hence have no real existence. What is real is "the feeling of Being, the immediate concept." The successive moments in the river of the soul's life—representations and desires_ " "are only its revelations."

A passage from the Short Presentation sheds light on what Schleiermacher means here. The passage in question is one in which Schleiermacher argues against the idea of an extramundane cause of the world. If the "infinite Monad" creates the world in such a way that it relates to a world that exists outside of it, "with what right does the infinite Monad not belong to the world?" For example, if we think of God as a kind of first cause, then we are thinking of God as standing in the same series of causes as all intra-mundane causes, and we cannot adequately distinguish God from the world. He notes, "It is, after all, the same in kind as the finite ones that make up the world, and between the two there is no other difference than that of degree, and this is not sufficient." Moreover the difference between the infinite Monad and the world cannot be the "immediacy," with which the infinite Monad represents the world. Such an idea is "indefensible, since representation cannot in any way be thought without a medium." Therefore, either the infinite Monad has

41 "space and time make up what is characteristic of our form of representation" (KGA I.1, 575). 
its own Monad-body, and is thereby a single individual, in the wretched sense in which the Godhead, according to Spinoza, is impossible, or the whole world is its body and thereby with it makes up only one thing. Were Leibnizianism to count on the possibility of thought without a medium, then at least it is easy to show that this cannot contain a single representation nor single determinations of the will. It is therefore something undetermined, which, after all, cannot be real without determinations, and so we would be once again back to Spinoza. (KGA I.1, 570)

If the infinite Monad has its own representations and determinations of the will that are distinct from the world, then it is an individual in the same way that all finite things are individuals, and there can only be a difference of degree between the finite and the infinite. This is the "wretched sense in which the Godhead is impossible" according to Spinoza, for then it would be one individual among others. Yet God cannot be counted among the number of individuals, for God does not stand under a common genus with things. ${ }^{42}$ We can have no "general concept," of God, and as such, we cannot "give God the name of an individual;" in other words, God is not a thing among things, or an individual among individuals. But this is exactly how we think of God when we to try "distinguish God from the finite things," and think of God as "outside of them," that is, when we think of the world as different from God and God's determinations (KGA I.1, 569). If on the other hand, the infinite Monad is thought of as having no determinations, then it is nothing. The only other viable alternative, Schleiermacher argues, is to think of the world as God's determinations, and this brings us back to the Spinozistic relation. ${ }^{43}$

If God is not an individual among others, as Schleiermacher argues, then God can never be an object for consciousness. As Schleiermacher notes, the immediate concept-the feeling of Being, "can never be perceived." How then do we relate to it? It is given

42 So Schleiermacher, "subsumption under numbers takes place only then, and in the things that one has brought under a common genus" (KGA I.1, 568-9).

43 Lessing put forward a similar idea in his On the Reality of Things Outside God, where he argues that God does not reduplicate finite things such that they exist "outside" of God's ideas. Rather, finite things are identical with these ideas. See Lessing: Philosophical and Theological Writings, 32-33. For an analysis of Lessing's argument, see Henry E. Allison, Lessing and the Enlightenment, $70 \mathrm{ff}$. 
through the transcendental unity of apperception, in virtue of which all my representations are mine. Just like the immediate concept, this transcendental unity is not itself a representation. It is, rather, that function in virtue of which representations are brought to a unity. As such it is given immediately and never appears. It is the ground of all the self's representations, and not merely their sum. ${ }^{44}$ By the time he gives his lectures on Dialectic (the first set of lectures was given in 1811), Schleiermacher provides a much more nuanced account of the way he conceives the transcendental unity of apperception to relate to the immediate concept. There he claims that "the transcendental," as that which both grounds and surpasses consciousness, "is also the idea of Being in itself under two kinds or forms and modes that are contrary and yet related to one another, namely, the ideal and the real, as conditions of the reality of knowledge." ${ }^{45}$ Later on in the Dialectic he affirms that we can "completely abstract" from the distinction "between the transcendent and the transcendental." ${ }^{46}$ The distinction is one coined by Kant: when we speak of the transcendental, we speak merely of the conditions of the possibility of experience, and hence too, of the activity of the transcendental subject in making

44 As Sarah Schmidt notes in Die Konstruktion des Endlichen, "Das unmittelbare Selbstbewußtsein eint jedoch nicht nur die einzelnen Akte des Bewußtseins (ähnlich der Kantischen transzendentalen Apperception), sondern geht über das einzelne Subjekt oder Ich hinaus, indem es die Einheit des leidenden und handelnden Subjektes ist und als solche auch das Sein des Anderen einschließt, es ist 'gleichürprungliches Sein des Selbst und des anderen,' unser 'Für-uns-Selbst-Sein umfaßt unser gesamtes Sein für-anderes.' Da wir auch in unmittelbaren Selbstbewußtsein uns nicht als Stifter dieser Einheit erfahren, sondern sich uns vielmehr im Mangel ein Verweis auf etwas über uns Hinausgehendes zeigt, spricht Schleiermacher daher auch von einen "Abhängigkeitsgefühl" (159-60). Nevertheless, it is important to keep in mind, as I argue in the rest of the book, that a careful reading of the mature Schleiermacher shows that he does not simply identify the transcendent ground of consciousness with ultimate reality itself, but that rather, it is a rift in the immediate self-consciousness that signals the self's relation to ultimate reality. The idea is nicely captured by Manfred Frank in the introduction to his 2001 edition of Schleiermacher's Dialectic: "Das, was dem unmittelbaren Selbstbewußtsein [oder Gefühl] einleuchtet, wenn es zwischen dem einem und dem anderen Pol der Reflektions-Spaltung hin und herflackert, ist also nicht etwa die positive Fülle einer überreflexiven Identität, sondern vielmehr das Negative von deren Mangel" (92). See also Frank's chapter "Metaphysical foundations: A look at Schleiermacher's Dialectic" in The Cambridge Companion to Friedrich Schleiermacher, especially 26-33.

45 Dialektik: Aus Schleiermachers handscriftlichem Nachlasse, edited by L. Jonas, Berlin: 1839, III. Abt. Bd. 4/2, 77.

${ }^{46}$ Ibid. 38. 
experience possible. The transcendent, however, is that which lies beyond the limits of all possible experience. ${ }^{47}$ Here the transcendent and the transcendental are identified in that the idea of Being, as the unity between the real and the ideal, must be assumed as a condition of the possibility of knowledge. Despite his familiarity with Kant's arguments against the possibility of knowledge of the transcendent, in Spinozism Schleiermacher had already come to the conclusion that it is through the transcendental activity of the self that the soul comes into contact with what is genuinely real. At this point, however, he does not believe that there is a genuine principle of individuation, or that the soul is a genuine substance. As such, there is no ground of personal identity. This is the subject of our next chapter.

47 See Critique of Pure Reason, A295/ в352. 